\title{
$\mathrm{CFD}$ 시뮬레이션을 이용한 건축물 및 녹지배치가 외부 열환경에 미치는 영향 예측
}

\author{
김정호 · 손원득 ${ }^{1)} \cdot$ 윤용한 ${ }^{*}$ \\ 건국대학교 자연과학대학, ${ }^{1)}$ (주)이에이엔테크놀로지 \\ (2011년 10월 2일 접수; 2011년 11월 6일 수정; 2011년 12월 12일 채택)
}

\section{Prediction of Effect on Outside Thermal Environment of Building and Green Space Arrangement by Computational Fluid Dynamic}

\author{
Jeong-Ho Kim, Won-Duk Son ${ }^{1)}$, Yong-Han Yoon ${ }^{*}$ \\ College of Natural Science, Konkuk University, Chungju 380-701, Korea \\ ${ }^{1)}$ EAN technology Co., Ltd. Seoul 138-050, Korea \\ (Manuscript received 2 October, 2011; revised 6 November, 2011; accepted 12 December, 2011)
}

\begin{abstract}
This study forecasts changes in thermal environment and microclimate change per new building construction and assignment of green space in urban area using Computational Fluid Dynamics(CFD) simulation. The analysis studies temperature, humidity and wind speed changes in 4 different given conditions that each reflects; 1) new building construction; 2) no new building construction; 3) green spaces; and 4) no green spaces. Daily average wind speed change is studied to be; Case $2(2.3 \mathrm{~m} / \mathrm{s})>$ Case 3 . The result of daily average temperate change are; Case $3\left(26.5^{\circ} \mathrm{C}\right)>$ Case $4(24$. $\left.6^{\circ} \mathrm{C}\right)>$ Case $2\left(23.9^{\circ} \mathrm{C}\right)$. This result depicts average of $2.5^{\circ} \mathrm{C}$ temperature rise post new building construction, and decrease of approximately $1.8^{\circ} \mathrm{C}$ when green space is provided. Daily average absolute humidity change is analysed to be; Case $3(15.8$ $\left.\mathrm{g} / \mathrm{kg}^{\prime}\right)>$ Case $4\left(14.1 \mathrm{~g} / \mathrm{kg}^{\prime}\right)>$ Case $2\left(13.5 \mathrm{~g} / \mathrm{kg}^{\prime}\right)$. This also reveals that when no green spaces is provided, $2.3 \mathrm{~g} / \mathrm{kg}^{\prime}$ of humidity change occurs, and when green space is provided, $0.6 \mathrm{~g} / \mathrm{kg}$ change occurnd $4(1.8 \mathrm{~m} / \mathrm{s})$, which leads to a conclusion that daily average wind velocity is reduced by $0.5 \mathrm{~m} / \mathrm{s}$ per new building construction in a building complex.
\end{abstract}

Key Words : Thermal environment, Humidity, Temperature, Wind velocity

\section{1. 서 론}

최근 수년간 이상기후 현상이 지구촌 곳곳에서 발 생하면서 그 원인과 대책에 대한 관심이 세계적 관심 사가 되고 있다. 아프리카를 비롯한 일부 지역에서는

${ }^{*}$ Corresponding author : Yong-Han Yoon, College of Natural Science, Konkuk University, Chungju 380-701, Korea

Phone: +82-43-840-3538

E-mail: yonghan7204@kku.ac.kr
계속되는 가뭄에 따른 식량부족과 식수오염으로 인하 여 기근과 질병이 심각하며 또한 미국과 유럽 등 다른 지역에서도 폭설, 폭우 등의 현상이 과거 어느 때보다 자주 발생하여 막대한 경제적 피해뿐 아니라 인명피 해도 속출하고 있다. 과학자들의 분석에 의하면 이와 같은 이상기후의 빈번한 발생은 인간활동에 의해 발 생한 온실가스가 대기 중으로 다량 배출됨에 따라 지 구 기온이 상승하는 이른바 온실효과 즉, 열섬현상 (heat island)이 그 주원인으로 제시되고 있다(한국환 
경과학회, 2009).

최근 도시 열섬현상 규명과 완화를 위한 국제적 관 심이 한층 고조되고 있는 가운데 국내에서도 도시열 섬완화 및 건축물 외부공간설계에 관련된 기초적인 연구가 부분적으로 시도되고 있으나(남, 2008), 아직 국내에서는 많은 연구자료가 축적되지 않은 상태이 다. 특히 시뮬레이션을 통한 예측을 통한 건축 및 도시 계획 적용사례는 거의 없다. 도시 및 외부공간의 열환 경 완화 기법에 대한 연구는 주로 바람길 확보(서, 2009), 녹지에 의한 냉각효과(남, 2008; 조와 안, 2006) 등이 있으며 서(2007)는 공동주택단지의 외부 공간 열환경 개선을 위한 요인으로 지표면 방사능 개 선, 녹지면적의 증대, 바람길 유도 및 조성, 수경공간 및 투수면 확보, 옥상녹화의 도입 등을 제시하였다.

도시 열섬현상은 토지피복상태, 차량 및 공자으로 부터의 열방출, 기상조건, 대기오염 등 여러 요소들의 상호작용의 결과로 나타나고(Akbari 등, 1992; Civoni, $1998)$ 온열환경요소를 개인적 요소와 물리적 변수로 구분하여 제시한 이상우(1997)는 개인적 변수로 활 동량, 착의량, 나이, 성별을, 물리적 변수로 기온, 복사 온도, 기류, 습도를 제시하고 있다. 이렇듯 외부 열환 경에 크게 영향을 미치는 기상요인은 기온, 풍속 및 풍 향, 습도로 요약할 수 있다. Olgyay(1963)는 기온, 습 도, 기류의 요인을 조합하여 생체기후도(Bioclimatic chart)룰 고안하여 열환경의 쾌적조건과 자연형 조절 기법을 제시하였으며 이후 Ashrae(2009)는 생체기후 도를 온도와 습도를 고려한 건물생체기후도를 작성 하여 실내공간의 쾌적성을 증대시키는 방안을 제시 하였다.

외부 열환경에 영향을 주는 기후 인자들로서는 기 온, 습도, 일조 및 일사, 강우량, 풍향 및 풍속 등이 있 으나, 본 연구에서는 외부 열환경에 미치는 대표적 요 인으로 제시되고 있는 풍속 및 풍향, 온도, 습도를 선 정하여 열환경 및 미기후 변화를 예측하였다. 특히 도 시내 기류는 조성된 건축물에 인하여 풍향이 바뀌거 나 풍속이 느려지며 이로 인해 낮에 뜨거워진 열이 밤 까지도 외부로 빠져나가지 못해 열섬현상 및 열대야 현상의 주 원인으로 작용하기도 한다. 이런 문제를 해 결하고자 국토해양부에서는 2005 년부터 신도시계획 시 바람길 및 물길을 고려한 개발계획을 수립하도록
제시하고 있다.

본 연구는 건축물의 신축 그리고 녹지의 배치에 따 른 외부 열환경 변화과 미기후 변화를 예측하고자, 건 축물의 신축전 기상요인과 신축후의 기상요인을 비교 하였고 특히 녹지의 조건에 따른 외부 열환경 변화 요 인도 분석하였다. 이는 향후 도시 열섬저감 및 패시브 (passive) 건축물 외부공간계획의 기초자료로 활용가 능하다. 특히, 본 연구에서는 $\mathrm{CFD}$ 해석을 통하여 공 동주택 건설이 단지 및 주변지역에 미치는 기류분포, 온도, 풍속, 절대습도 등의 변화를 예측한 연구로서 시 뮬레이션 결과값과 실측값의 비교를 통한 정확한 일 치도를 얻는 결과보다는 공동주택 건설에 따른 미기 상 변화의 패턴이나 경향을 확인하여 저탄소 친환경 공동주택 건설을 위한 환경예측의 기초자료로 활용하 고자 하였다.

\section{2. 시뮬레이션의 개요 및 선행연구 검토}

\subsection{CFD 시뮬레이션 개요}

전산유체역학(Computational Fluid Dynamics, $\mathrm{CFD})$ 은 컴퓨터를 이용한 수치해석이며 계산과학의 한 분야이다(김, 1998). CFD는 1960년대에 들어서면 서 컴퓨터의 급속한 발달과 함께 과거에 이론적으로 해석할 수 없었던 복잡한 열 및 유체유동에 대한 수치 해석적이 가능하게 되었으며 최근 하드웨어적인 컴퓨 터의 발달과 함께 수치적 연구분야가 비약적 발전을 하게되었는데, 이런 수치적 연구분야를 전산유체역학 분야라고도 통칭한다. $\mathrm{CFD}$ 는 주로 건축분야에서는 국부적인 실내 기류에 이용되었으나, 컴퓨터 성능의 발달과 함께 아트리움, 쇼핑몰 및 공항 전시공간 등 대 공간의 온도분포, 기류속도 및 방향, 난류분포, 오염물 질 확산 등에 사용되어져 오다가 최근 친환경 도시 및 건축물의 건설과 맞물려 외부공간의 온도, 대류해석 에 많이 이용되고 있다(김, 1998).

수치해석을 이용하면 디테일한 차원에서의 시뮬레 이션이 가능하며 유사한 작업의 반복 수행시 비교적 신속하고 저렴한 비용으로 예측 및 검증을 할 수 있는 장점이 있다. 특히 $\mathrm{CFD}$ 를 이용한 수치해석과 복사 열 전달 등을 연성 해석하는 것이 가능하여 복잡한 실태 를 정량적으로도 해석 가능하다. 지금까지 CFD 시뮬 
레이션이 기계분야와 건축분야를 중심으로 많이 적용 되어 왔으나, 최근 환경친화적 도시 및 단지 건설, 도 시열섬완화 등을 구현하기 위해 $\mathrm{CFD}$ 를 활용한 예측 이 이용되기 시작하였다. 본 연구에서는 $\mathrm{CFD}$ 를 활용 하여 공동주택단지의 건설이 단지내부 및 외부에 미 치는 열환경 변화를 예측하여 환경친화적 도시 및 지 역개발의 기초자료로 활용하고자 하였다.

친환경 분야의 상용 CFD 소프트웨어로는 Star-CD, Star-CCM+, Phoenics, Fluent 등이 있으며(남, 2008), 본 연구에서는 Star-CCM+(v3.02)를 이용하였다. Star-CCM+은 영국 Imperial college의 A.D. Gosman 교수팀에 의해 개발되어 1985년부터 상용화되어 미 국, 영국, 독일, 일본, 프랑스 등 전세계적으로 널리 사 용되고 있는 범용 열 - 유체 해석 소프트웨어이다.

일반적으로 $\mathrm{CFD}$ 를 이용한 수치해석 방법은 고려 가 가능한 요소들을 반영하여 모형실험보다 경제적으 로 결과를 얻을 수 있는 장점이 있어 상대적으로 짧은 시간에 효과적인 결과를 예측할 수 있어 이를 적용한
예측 및 평가가 많이 이루어지고 있다(윤과 주, 2011). 본 연구에서는 $\mathrm{CFD}$ 를 활용하여 공동주택단지 건설에 따른 외부 열환경의 변화를 예측하였으며 대표적인 물리량 보존법칙인 질량보존의 법칙과 운동량 보존의 법칙으로부터 도출한 다음의 연립편미분방정식을 지 배방정식으로 채택하였다. 난류모델로는 온열환경평 가에서 실용적으로 흔히 적용하고 있는 표준 $\kappa-\varepsilon$ model을 사용하였으며 물리적 모델 방정식인 $\kappa-\varepsilon$ model의 수식은 Table 1과 같이 표현된다.

\section{2. 선행연구 검토}

국토의 난개발에 대한 대응으로 전략환경영향평가 (이와 이, 2001)와 PSR (pressure, state, response) 지 표개발(이와 전, 1997; 윤 등, 1999) 등이 이루어지고 있으며 도시 및 택지개발단위로는 비오톱 유형을 고 려한 환경생태계획의 적용(김과 한, 2006; 이, 2007) 등이 이루어지고 있으나, 이는 주로 생태계 속성 복원 및 보전을 제시한 연구로 최근의 기후변화 및 도시열

Table 1. Physical model equation( $\kappa-\varepsilon$ model)

\begin{tabular}{|c|c|}
\hline Division & Equation \\
\hline Sequence calculation & $\frac{\partial}{\partial x_{i}}\left(\rho u_{i}\right)=0$ \\
\hline Momentum equation & $\frac{\partial}{\partial x_{j}}\left(\rho u_{i} u_{j}\right)=-\frac{\partial p}{\partial x_{i}}+\frac{\partial \tau_{i j}}{\partial x_{j}}$ \\
\hline Energy equation & $\begin{array}{l}\frac{\partial}{\partial t}(\rho h)+\frac{\partial}{\partial x_{i}}\left(\rho u_{i} h\right)=\frac{\partial P}{\partial t}+\frac{\partial}{\partial x_{i}}\left(\lambda_{t-i}\right) \frac{\partial T}{\partial x_{i}}+Q \\
\lambda_{t}=\frac{\mu_{t}}{\operatorname{Pr}_{t}}, C_{1} \epsilon=1.44, C_{2} \epsilon=1.92, C_{\mu}=0.09, \sigma_{k}=1.0, \sigma_{\epsilon}=1.3\end{array}$ \\
\hline $\begin{array}{l}\text { Turbulence } \\
\text { kinetic equation }\end{array}$ & $\frac{\partial}{\partial x_{i}}\left(\rho u_{i} k\right)=\frac{\partial}{\partial x_{i}}\left(\mu+\frac{\mu_{t}}{\sigma_{k}}\right) \frac{\partial k}{\partial x_{i}}+G-\rho \epsilon$ \\
\hline $\begin{array}{l}\text { Turbulence } \\
\text { kinetic equation } \\
\text { dissipation rate equation }\end{array}$ & $\begin{array}{l}\frac{\partial}{\partial x_{i}}\left(\rho u_{i} \epsilon\right)=\frac{\partial}{\partial x_{i}}\left(\mu+\frac{\mu_{t}}{\sigma_{\epsilon}}\right) \frac{\partial \epsilon}{\partial x_{i}}+\frac{\epsilon}{k}\left(C_{1} G-C_{2} \rho \epsilon\right) \\
\tau_{i j}=\left(\mu+\mu_{t}\right)\left(\frac{\partial u_{j}}{\partial x_{i}}+\frac{\partial u_{i}}{\partial u_{j}}\right)-\frac{2}{3} \rho k \delta_{i j} \\
\mu_{t}=C_{\mu} \rho \frac{k^{2}}{\epsilon} \\
G=\mu_{t} \frac{\partial u_{i}}{\partial x_{j}}\left(\frac{\partial u_{j}}{\partial x_{i}}+\frac{\partial u_{i}}{\partial u_{j}}\right) \\
C_{1}=1.44, C_{2}=1.92, C_{\mu}=0.09, \sigma_{k}=1.0,779 \sigma_{\epsilon}=1.22\end{array}$ \\
\hline
\end{tabular}


섬을 반영한 친환경 계획기법 및 예측 연구가 매우 필 요한 시점이다. 지금까지 도시 열섬현상 등 도시환경 문제를 해결한 연구로는 도시열섬에 건축물 외부공간 이 미치는 영향(김 등, 2010), 도시열섬과 토양피복(조 등, 2009)에 관한 기초적인 연구가 부분적으로 시도되 고 있으나, 주로 실측을 중심으로 이루어져 왔다. 그러 나 외부공간의 단기간 실측에 의한 데이터 오류가 심 각하여 최근에는 경제성과 정확성이 고려된 시뮬레이 션을 활용하여 도시열환경 예측과 이를 활용한 설계 기법에의 도입 시도가 이루어지고 있는데(박, 2009), 건축물의 배치에 따른 외부 미기상 변화(고, 2010), 토 양피복과 도시 고온화의 영향 연구(윤과 김, 2008; 류 와 유, 2006), 신재생에너지가 도시열수지에 미치는 영향 연구(손 등, 2009) 등이 있으며 건축물의 배치와 녹지의 규모를 함께 고려한 예측 시뮬레이션 연구는 매우 부족하였다.

시뮬레이션을 통한 예측은 실제모의실험에 의해 얻어진 값과 유사한 경향을 나타내는 연구가 지속적 으로 진행되어 최근에는 모의실험과 실측보다 시뮬레 이션에 의한 값을 통한 영향분석 및 대안수립에 많이 활용되고 있다. 옥외 열환경평가 관련 시뮬레이션 중 도시 도시블럭 스케일의 도시기후시뮬레이션으로 서는 村上(1997), 김과 서(2002) 등은 Meller-Yamada 대기난류모델을 이용하여 도시레벨의 풍속분포, 온도 분포 등 국지적인 기후해석을 행하였다. 그러나 블록 단위 스케일을 다루은 수치해석 연구로는 吉田 등 (2000), 김 등(2000), 김과 윤(2011), 손과 이(2004) 등 에 의해 이루어졌지만, 지역별 혹은 토지이용별로 더 많은 연구가 진행되어야 할 것이다. CFD 시뮬레이션 예측결과값과 실측값을 비교하여 정확도 및 경향의 유사성을 검증한 연구(김 등, 2010; 남, 2008; 석 등, 2009)에서도 확인되었듯이 향후 도시 및 단지계획 수 립전 시뮬레이션을 통한 환경예측을 실시한 후 이를 토대로 친환경 계획 및 설계를 수립하여야 할 것이다.

본 연구는 경기도 지역에 건설예정인 공동주택단 지를 대상으로 도시블럭 스케일 수준의 정밀한 예측 을 위해 CFD 시뮬레이션을 적용하여 건축물과 녹지 의 규모에 따른 영향을 예측하여 향후 친환경 단지 및 도시계획의 기초자료로 활용하고자 하였다.

\section{3. 재료 및 방법}

\section{1. 분석대상지}

본 연구는 건축물의 신축에 따른 외부 열환경 변화 를 예측하고자 경기도 수원지역에 위치한 대규모 공 동주택단지를 선정하였다. 연구대상지는 대지면적 $69,500 \mathrm{~m}^{2}$ 이며 이중 건축면적은 7,200 $\mathrm{m}^{2}$ 이다. 건물연 면적은 $110,190.0 \mathrm{~m}^{2}$ 이었으며 최고높이 $47 \mathrm{~m}$, 건페율 $10.0 \%$, 용적율 $99.0 \%$ 이었다.

$\mathrm{CFD}$ 시뮬레이션을 통한 외부 열환경의 변화를 비 교하기 위한 분석지점 설정은 설계도면을 참조하여 음영영향, 일사영향, 녹지배치 조건 등을 고려하여 아 래와 같이 총 10 개 지점(P1 P10)을 선정하였다.

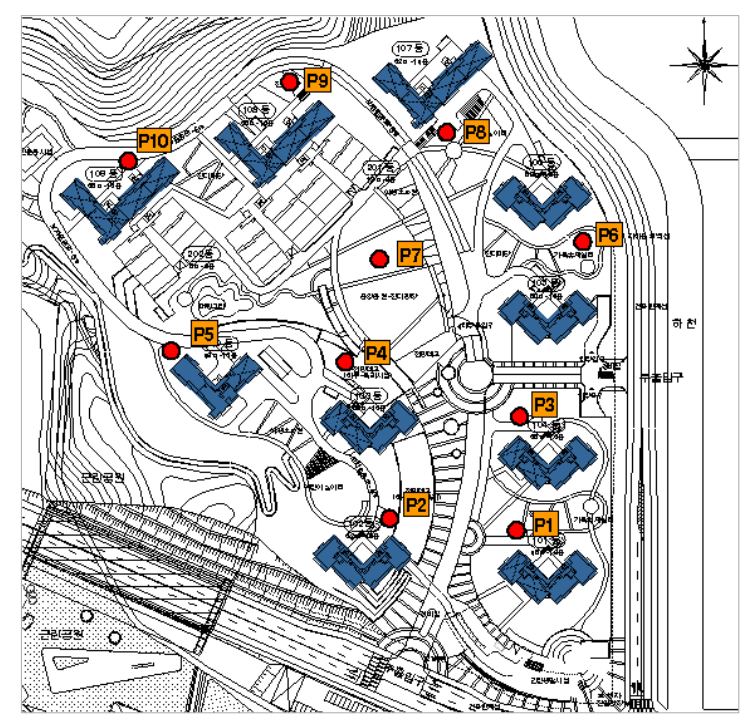

Fig. 1. The location map of analysis points.

\section{2. 분석절차 및 해석방법}

본 연구는 대상지의 기상현황을 토대로 시뮬레이 션 변수를 도출하고 분석된 기상 및 설계조건을 고려 하여 분석점 및 모델리을 실시하였으며 이를 통해 시 뮬레이션 결과 산출과 외부 열환경 변화 예측을 실시 하였다. 


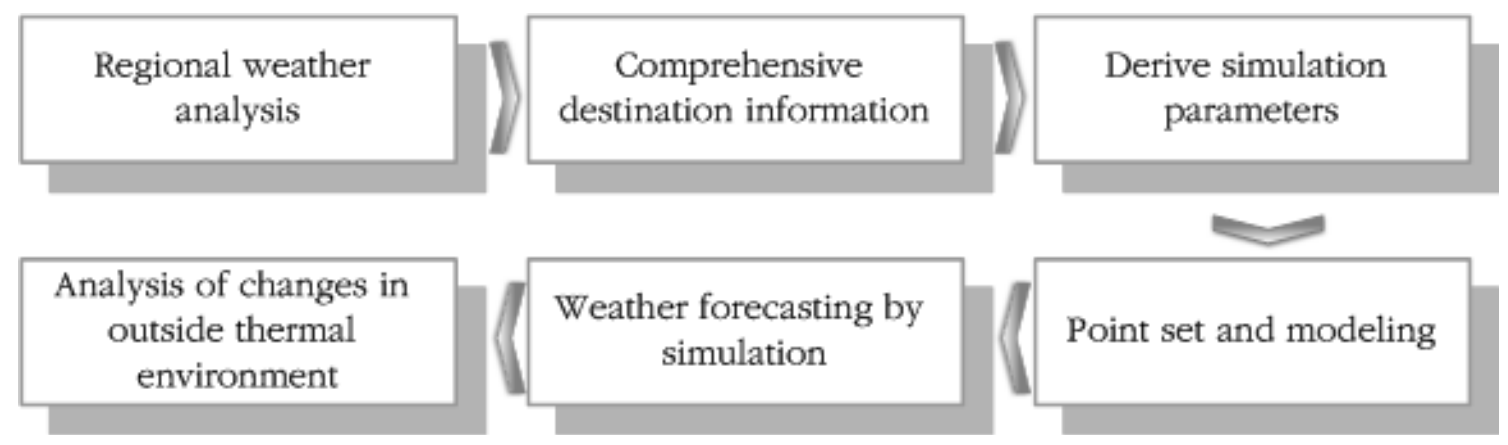

Fig. 2. Flowchart of outside thermal environment by simulation.

\section{3. 경계조건 및 해석조건(Case) 설정}

본 연구에 적용한 시뮬레이션의 경계조건은 수원 기상대의 10년(2000 2009)간 기상청 자료를 인용하 였다(기상청, 2010). 단지 내 외부 열환경 해석을 위해 $\mathrm{CFD}$ 기법을 이용하였으며, 주변 지형을 고려한 전체 공간을 약 120 만개의 Trimmed mesh로 구성하였다. 단지의 모델링은 주변 지형을 고려한 실제 단지와 유 사하게 모델링 하였으며, 실제 단지 녹지율을 그대로 반영하였다. 아울러 복사와 대류를 고려하여 시뮬레 이션을 실시하였다(손 등, 2009).

해석조건은 기존 연구결과와 대상지의 지형, 설계 조건 등을 고려하여 총 4가지 유형으로 설정하였다. 해석조건은 건축물의 조성이 외부 열환경에 미치는 영향을 예측- 검증하고자 신축 전후의 바람길 유무, 신축전과 후의 온도, 절대습도, 풍속 그리고 신축된 건 물의 녹지규모를 고려하여 선정하였다. Table 2는 Case별 해석조건을 제시한 것으로서 Case 1은 건축물

(a) Outside modeling

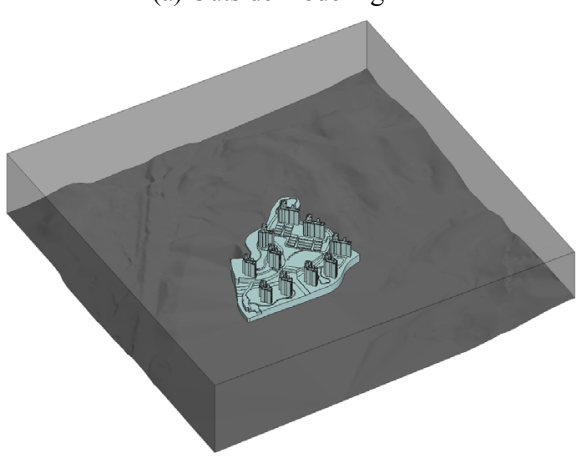

신축 전·후의 바람길 변화, Case 2 는 건물 신축전, Case 3 는 건물 신축후(녹지공간을 계획하지 않은 경 우), Case 4는 건물 신축후(녹지공간이 계획된 경우) 의 조건이다. 단, 건물 외피 및 열수지는 반영하지 않 았다.

Table 2. Condition

\begin{tabular}{cl}
\hline Division & \multicolumn{1}{c}{ Item } \\
\hline \hline Case 1 & $\begin{array}{l}\text { Before and after of new building developing, } \\
\text { change of air movement and wind velocity }\end{array}$ \\
\hline Case 2 & $\begin{array}{l}\text { Temperature, humidity and wind velocity of } \\
\text { before new building construct at summer season }\end{array}$ \\
\hline Case 3 & $\begin{array}{l}\text { Temperature, humidity and wind velocity of after } \\
\text { new building construct at summer season(green } \\
\text { areas ratio 0\%) }\end{array}$ \\
\hline Case 4 & $\begin{array}{l}\text { Temperature, humidity and wind velocity of after } \\
\text { new building construct at summer season(green } \\
\text { areas ratio 40\%) }\end{array}$ \\
\hline
\end{tabular}

(b) Grid modeling

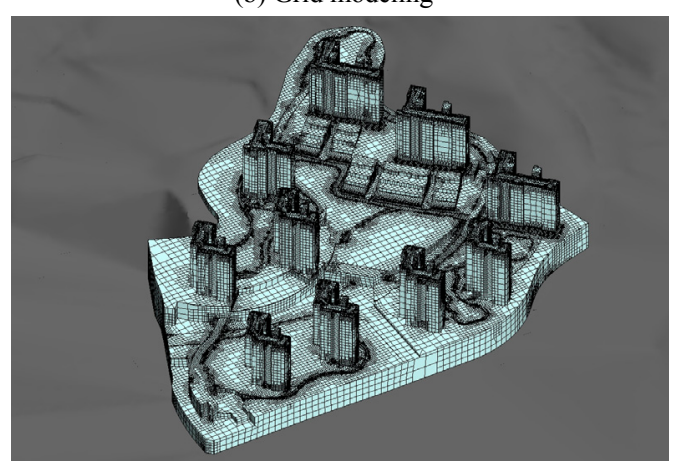

Fig. 3. Modeling of topography. 


\section{4. 결과 및 고찰}

\section{1. 지역 기후환경 분석}

연구대상지가 속한 지역의 도시열섬 및 온난화 특 성을 분석하기 위해 해당 지역 기상관측소 $\left(37^{\circ} 16^{\circ} \mathrm{N}\right.$ $\left.126^{\circ} 59^{\prime} \mathrm{E}\right)$ 를 참조로 최근 10 년간(2000 2009년)간 기상자료를 분석하였다. 단지 외부 온열환경에 영향 을 주는 기후인자들로는 기온, 습도, 일조 및 일사, 강 우량, 풍향 및 풍속 등 있으며(이, 1987) 이중 외부 열 환경 및 쾌적성과 연관성이 큰 연평균 기온, 풍속, 상 대습도(이, 1997)를 선정하여 전국 10 년간 연평균 기 상현황과 비교분석하였다.

연구대상지가 속한 수원지역의 10 년간 연평균 기 온은 $12.4{ }^{\circ} \mathrm{C}$, 연평균 풍속은 $1.9 \mathrm{~m} / \mathrm{s}$ 이었고 연평균 상 대습도는 $65.7 \%$ 이었다. 전국의 최근 10 년간 연평균 기온은 $12 .{ }^{\circ} \mathrm{C}$, 연평균 풍속 $2.2 \mathrm{~m} / \mathrm{s}$, 연평균 상대습도 $67.2 \%$ 보다 연구대상지가 속한 지역이 다소 낮았지만, 연구대상지인 수원지역의 과거 30 년간 기상자료와 비 교한 결과, 연평균기온은 $0.6^{\circ} \mathrm{C}$, 연평균풍속은 $0.3^{\circ} \mathrm{C}$ 증가한 것으로 나타나 최근 도시열섬화의 영향이 진 행되고 있는 것으로 판단되었다.
연간 주풍향은 서풍계열이었으며 이중 서풍이 $12.3 \%$ 로 가장 빈도가 높았다. 계절별로는 봄과 여름은 서풍이 각각 $9.4 \%, 11.5 \%$ 이었고 가을과 겨울은 서북서풍이 각각 $9.4 \%, 15.2 \%$ 로 나타나, 연간 서풍계열이 주풍향 이었다. 본 연구에서는 공동주택 신축에 따른 외부 열 환경의 변화특성을 분석하고자 하였으므로 도시 열섬 현상이 주로 발생하는 여름철을 대상으로 하여 주풍 향을 서풍으로 선정하여 시뮬레이션을 실시하였다.

\subsection{Case 1 : 건축물 신축 전·후 바람길 변화}

외부 열환경에 영향을 미치는 요인을 분석한 이 등 (2010)은 풍속, 음영, 지면상태, 풍향의 순으로 나타나 며 외부 열환경에 가장 큰 영향을 미치는 요인이 풍속 임을 검증하였다. 아울러 단지내부의 CFD 시뮬레이 션과 실측을 통해 외부 열환경의 오차를 분석한 결과 시뮬레이션에 의한 예측결과가 실측결과와 유사하게 분석되어 시뮬레이션에 의한 외부 열환경 평가에 대 한 타당성을 제시한 바 있다.

도시 열환경 개선을 위해 풍속 및 풍향과 관련한 기 존의 연구결과를 종합해 보면, 열섬의 발달은 풍향과 풍속에 의해 다르게 나타나며(이 등, 2010), 바람길은

Table 3. Wind direction and wind rose(2000 2009)

\begin{tabular}{|c|c|c|c|c|c|}
\hline Division & Annual average & Spring & Summer & Autumn & Winter \\
\hline Wind direction & $\mathrm{W}$ & $\mathrm{W}$ & $\mathrm{W}$ & WNW & WNW \\
\hline Ratio(\%) & 12.3 & 9.4 & 11.5 & 9.4 & 15.2 \\
\hline Wind rose & SSW & s & ${ }_{15}^{N W 20}{ }^{\mathrm{N}}$ & ${ }^{N}{ }^{2}{ }^{N}{ }^{N}$ & $\begin{array}{c}\text { W2O } \\
15 \\
10 \\
5 \\
0\end{array}$ \\
\hline
\end{tabular}

(a) Temperature

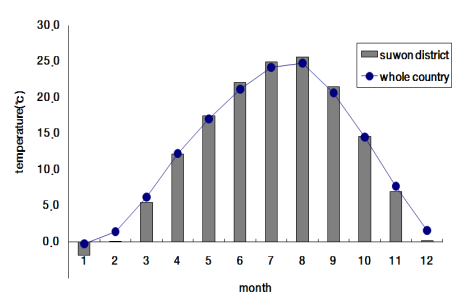

(b) Relative humidity

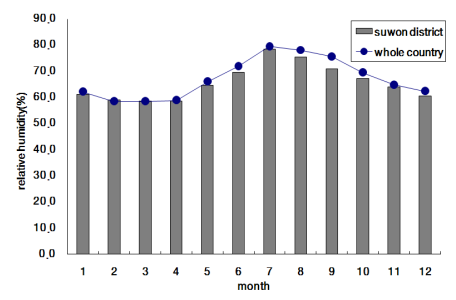

(c) Wind velocity

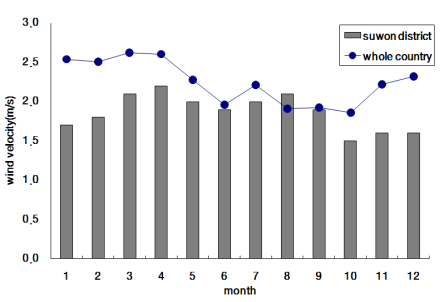

Fig. 4. Weather data whole country and suwon district(2000 2009). 
도시 및 단지내 대기오염 및 도시열섬 현상과 같은 환 경문제의 완화를 위해 계획시 반영되는 요소(정 등, 2007)로서, 바람길은 일정한 방향으로 바람이 불어가 는 통로(corridor)를 의미하며 바람길을 따라 흐르는 기류는 주변지역의 지배적인 기상조건에 크게 영향을 받지 않는다(서, 2007).

본 연구대상지의 건물 신축 전 나대지 상태의 평균 풍속은 $2.2 \mathrm{~m} / \mathrm{s}$ 로 나타났으며, 바람장애를 유발할 구 조물이 없으므로 하절기 주풍향(서풍)에 순응한 바람 길을 형성하고 있었다. 건물 신축 후 평가 대상지의 평 균 풍속은 $1.8 \mathrm{~m} / \mathrm{s}$ 로 나타나 건물 신축 전 대비 약 0.5 $\mathrm{m} / \mathrm{s}$ 감소하였다. 이는 건축물의 조성으로 바람의 흐름 을 변형하거나 건물 후류역의 정체역이 발생하기 때 문인 것으로 판단되었다. 일반적으로 바람길을 고려 한 건축물 배치는 바람에 순응하도록 판상형 배치가 가장 양호하며 판상형 주동이 바람길에 수직으로 배 치된 경우와 수평으로 배치된 경우에 단지 외기온도 차이는 약 $0.2{ }^{\circ} \mathrm{C}$ 정도 차이가 난다(서, 2007). 본 연구 대상지는 $\mathrm{V}$ 자형 주동배치로 형성되어 있어 전체적 단 지배치는 기류의 흐름에 순응토록 계획되었으나, 주 동건물 후면의 정체역 발생이 생기고 있어 향후 피로 티 계획 등이 이루어져야 할 것이다.

주동 후면에 풍속 저하역에서는 최소 풍속이 0.4 $\mathrm{m} / \mathrm{s}$ 유지되고 있었고 단지 동측 경계에 인접한 대지의 풍속은 약 $1.5 \mathrm{~m} / \mathrm{s}$, 또 동측으로 약 $100 \mathrm{~m}$ 이격한 위치 의 풍속은 $1.8 \mathrm{~m} / \mathrm{s}$ 로 예측되어, 건물 신축 이전 대비

(a) Before

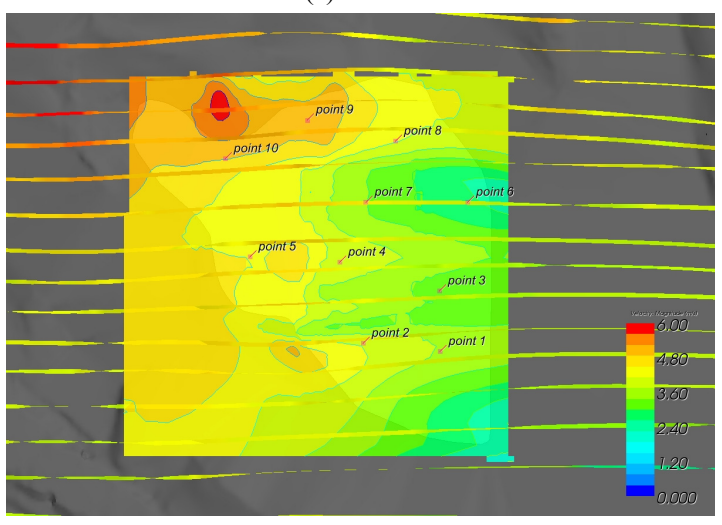

$0.5 \sim 0.9 \mathrm{~m} / \mathrm{s}$ 의 풍속저하가 발생하고 있었다. 대도시 인 미국 워싱턴의 방대한 기온관측으로부터 수집한 자료를 체계적으로 분석한 기존 연구에서는 강한 바 람은 도시내 최고기온을 동일하게 형성하며, $3 \mathrm{~m} / \mathrm{s}$ 이 하의 풍속에서는 도심내부와 외부와의 온도차이가 $6{ }^{\circ} \mathrm{C}$ 이상 발생시킬 수 있다(한국환경과학회, 2009)고 하였다. 본 연구에서도 분석되었듯이 바람의 흐름은 단지내 열섬 및 외부 열환경의 변화를 야기하는 가장 주된 요인이므로 향후 건축계획시 바람길을 고려한 배치가 우선 되어야 할 것이다.

\subsection{Case 2 : 건축물 신축 이전 여름철 온도, 절대습도,} 풍속 해석

Case 1에서 연구대상지가 위치한 지역 미기상과의 특성을 비교한 결과를 토대로 건축물 신축 전·후의 차이를 예측하고자 Case 2에서는 건축물 신축전의 여 름철 온도, 절대습도, 풍속을 예측하였다. 해석은 주간 과 야간으로 구분하여 실시하였으며 주간은 06시부터 20 시까지, 야간은 20 시부터 익일 06시까지를 대상으 로 하였으며 이를 평균하여 분석지점별 주간과 야간 의 평균값으로 대체하였다.

신축전의 주간 평균 외기온도는 $24.9^{\circ} \mathrm{C}$ 이었으며 야 간은 $22.4^{\circ} \mathrm{C}$ 로서 주간과 야간의 평균 외기온도 차이 는 약 $2.5^{\circ} \mathrm{C}$ 로 해석되었다. 분석지점별로 살펴보면 (Fig. 6), 주간에는 중앙부 서측에 위치한 P5가 $24.0^{\circ} \mathrm{C}$ 로 가장 낮게 나타났고 분석대상지역의 가운데에 위 치한 $\mathrm{P} 7$ 이 $25.5^{\circ} \mathrm{C}$ 로 가장 높게 예측되었다. 야간의 경

Fig. 5. Change of air movement for new buildings constructure.

(b) After

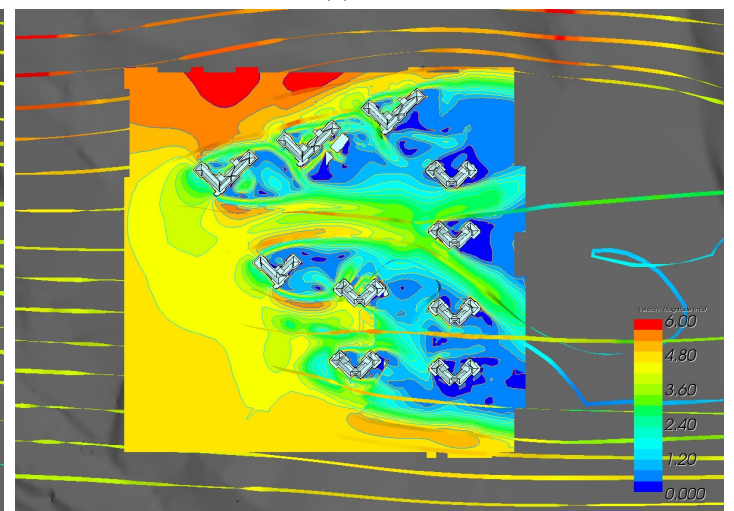


우에도 주간과 동일한 경향을 보이고 있었으며 야간 으로 설정한 기간 동안 평균 외기온도는 $22.4^{\circ} \mathrm{C}$ 로 $\mathrm{P} 5$ 가 $21.3^{\circ} \mathrm{C}$ 로 가장 낮았고 $\mathrm{P} 7$ 지역이 $23.1^{\circ} \mathrm{C}$ 로 가장 높 게 예측되었다. 이는 연구대상지가 포함된 지역 기상 청(2010) 자료와 유사한 경향이었다.

절대습도는 평균 주간 $13.3 \mathrm{~g} / \mathrm{kg}^{\prime}$, 야간 $13.9 \mathrm{~g} / \mathrm{kg}^{\prime}$, 일평균 $13.6 \mathrm{gg} / \mathrm{kg}^{\prime}$ 이었다. 일평균 절대습도를 상대습 도로 환산시 $76.3 \%$ 로서 해당 지역 기상대의 평균 상 대습도 $75.8 \%$ 와 유사하였다. 풍속은 주간 $2.7 \mathrm{~m} / \mathrm{s}$, 야 간 $1.7 \mathrm{~m} / \mathrm{s}$ 으로 나타나 해당 기상대에서 제시한 평균 값과 주간 $0.4 \mathrm{~m} / \mathrm{s}$, 야간 $0.3 \mathrm{~m} / \mathrm{s}$ 의 차이를 나타내었다.
즉, 신축 이전 연구대상지는 해당 지역의 기상환경과 거의 유사한 조건으로 해석되었다.

\subsection{Case $3:$ 건축물 신축이후(녹지율 $0 \%$ ) 여름철 온도,} 절대습도, 풍속 해석

공동주택 신축 이후 녹지가 없고 단지 포장만으로 외부공간이 조성되었을 경우를 가정한 Case 3 의 경우, 주간 평균온도는 $24.7^{\circ} \mathrm{C}$, 야간 평균온도 $24.6^{\circ} \mathrm{C}$, 일 평 균 $26.1^{\circ} \mathrm{C}$ 로서 신축전인 Case 2 와 비교해 볼 때, 주간 $2.8^{\circ} \mathrm{C}$, 야간 $2.2^{\circ} \mathrm{C}$, 일간 $2.5^{\circ} \mathrm{C}$ 높게 나타나 건축신축 과 포장이 단지내 온도 상승에 영향을 미치고 있었다.

(a) Average of daytime

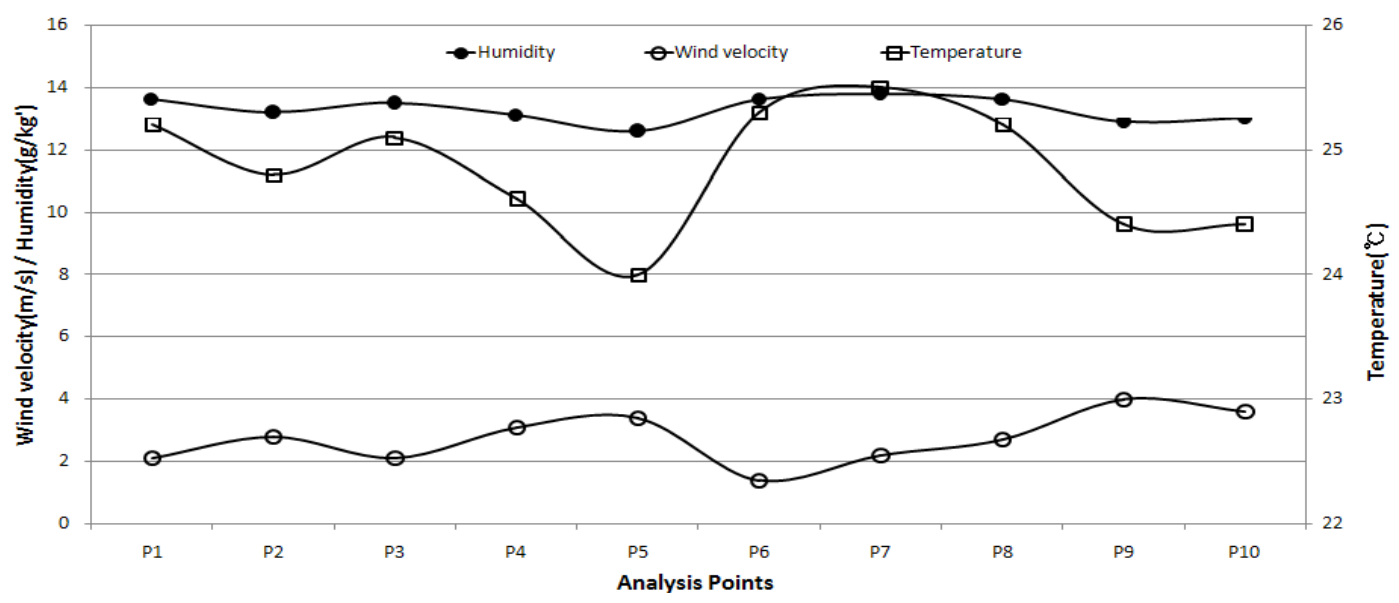

(b) Average of nighttime

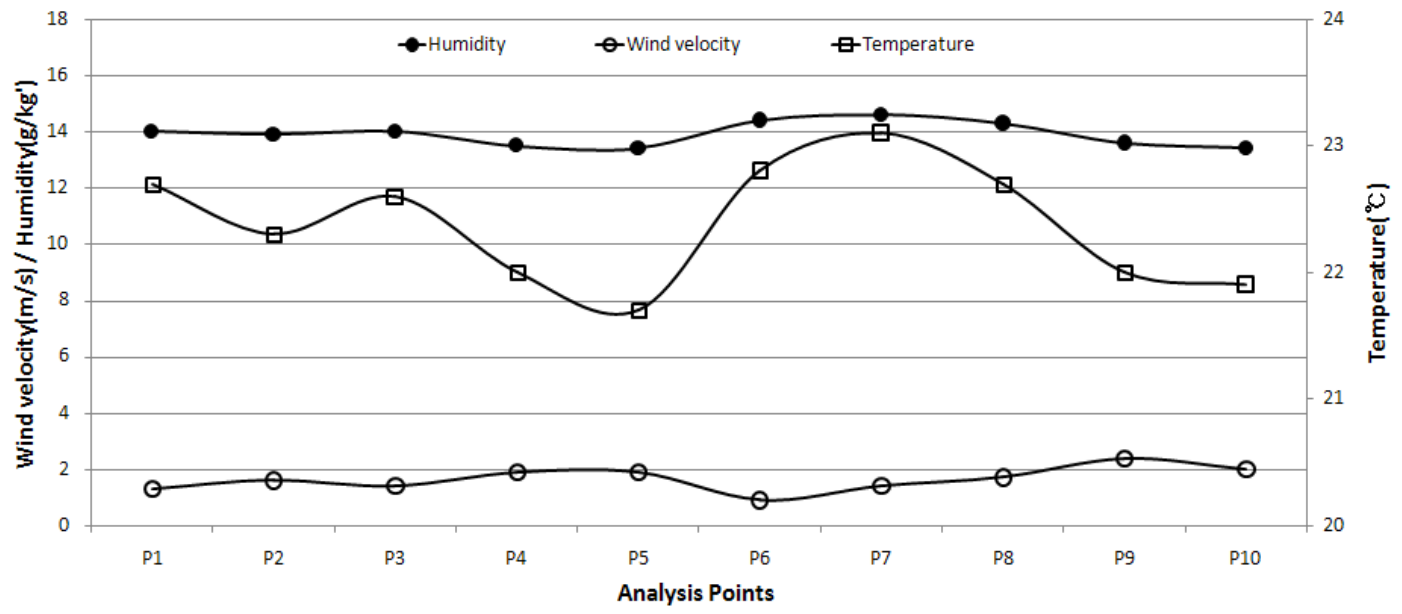

Fig. 6. Temperature, humidity and wind velocity of Case 2 at summer season. 
이는 도시화 및 표면상태가 도시기온의 상승을 일으 킨다는 연구(김과 윤, 2011; 남, 2008; 윤과 김, 2008) 와 동일한 경향으로 예측되었다. 분석지점별로는 $\mathrm{P} 4$ 가 $27.1^{\circ} \mathrm{C}$ 로 가장 높게 분석되었고 $\mathrm{P} 5$ 가 $23.1^{\circ} \mathrm{C}$ 로 가 장 낮게 분석되었다. 이는 P5의 경우 단지 전면에 배 치되어 기류에 의해 온도가 낮아진 것으로 예측되었 으며 P4의 경우 단지 중앙부에 위치하여 기류 정체 및 주변 불투수포장면의 영향을 가장 많이 받았기 때문 으로 판단되었다. 야간의 경우에도 주간과 유사하게 분석지점별로 동일한 경향을 보이고 있었지만, 평균 외기온도값은 $27.6^{\circ} \mathrm{C}$ 로서 주간보다 $2.9^{\circ} \mathrm{C}$ 높았다. 이
는 주간에 축열된 열이 야간에 방출되기 때문으로 판 단되었다.

절대습도의 경우 주간평균 $15.8 \mathrm{~g} / \mathrm{kg}^{\prime}$, 야간 15.9 $\mathrm{g} / \mathrm{kg}^{\prime}$ 로서 주 - 야간 값은 유사하였다. Case 2 대비 주 간 $2.5 \mathrm{~g} / \mathrm{kg}^{\prime}$, 야간 $2.0 \mathrm{~g} / \mathrm{kg}^{\prime}$, 일간 $2.5 \mathrm{~g} / \mathrm{kg}^{\prime}$ 높게 나타 났다. 이는 온도상승에 의한 포화수증기량 증가의 영 향이며 인체 온열감의 불쾌적 요인으로 작용할 것으 로 예측되었다. 에너지 시뮬레이션을 위한 표준 외기 온도 및 절대습도 데이터 수식화를 연구한 김과 김 (2002)은 외기온도가 시간대에 절대습도가 높게 나타 났으며 계절별로는 여름철이 겨울철보다 절대습도가

(a) Average of daytime

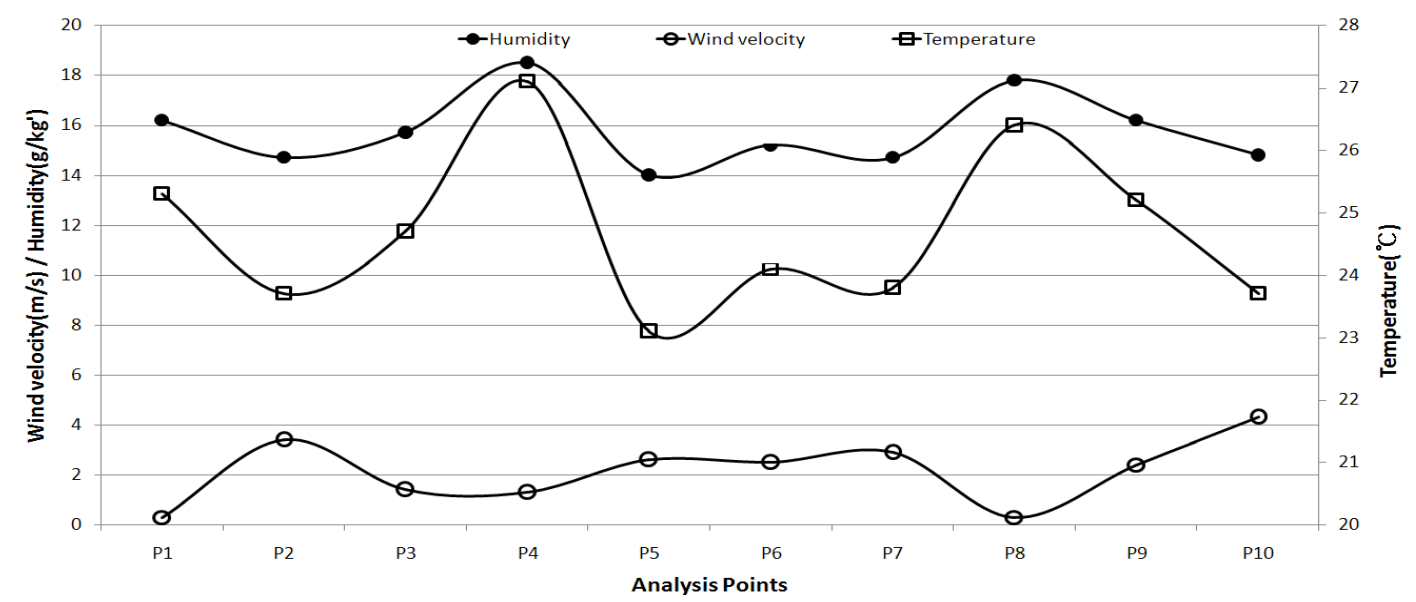

(b) Average of nighttime

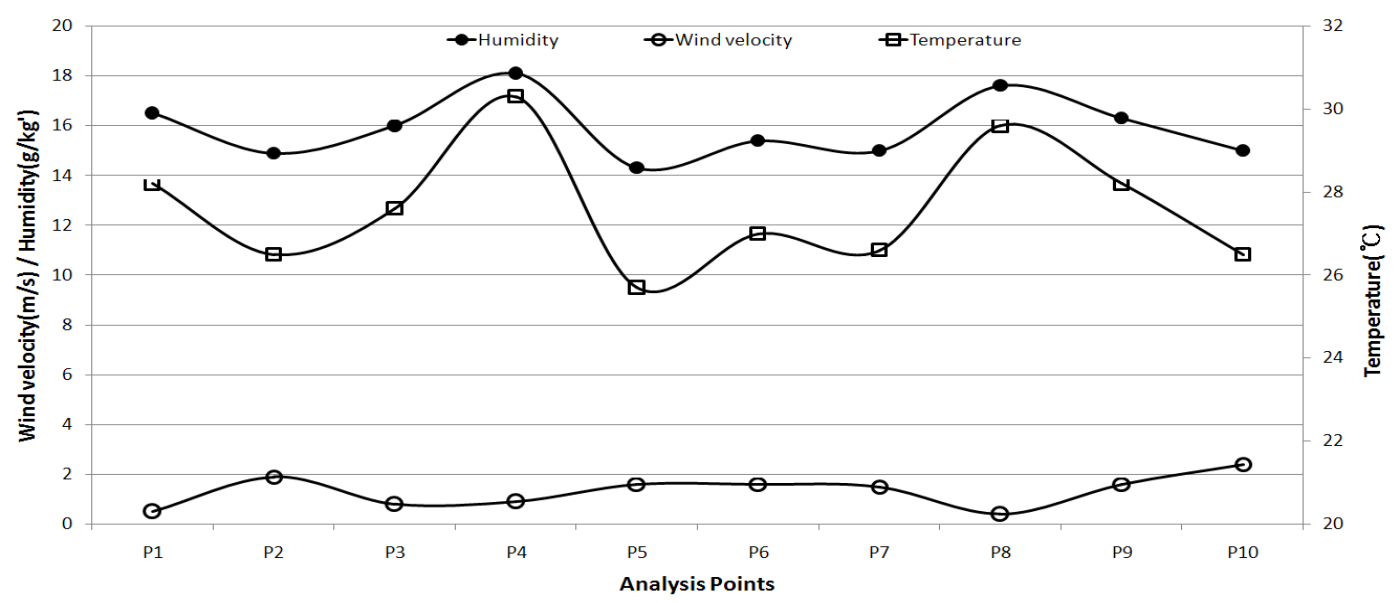

Fig. 7. Temperature, humidity and wind velocity of Case 3 at summer season. 
높게 나타나는 경향을 검증하였다. 분석지점별로는 온도와 마찬가지로 $\mathrm{P} 4$ 지점이 주간 $18.5 \mathrm{~g} / \mathrm{kg}^{\prime}$, 야간 $18.1 \mathrm{~g} / \mathrm{kg}^{\prime}$ 로서 가장 높았고 P5지점이 주간 $14.0 \mathrm{~g} / \mathrm{kg}^{\prime}$, 야간 $14.3 \mathrm{~g} / \mathrm{kg}^{\prime}$ 으로 가장 낮았다.

풍속은 주간평균 $2.2 \mathrm{~m} / \mathrm{s}$, 야간평균 $1.3 \mathrm{~m} / \mathrm{s}$ 로 분석 되어 신축 이전을 가정하여 분석한 Case 2 와 비교해 보면, 주간 평균 $0.6 \mathrm{~m} / \mathrm{s}$, 야간 평균 $0.3 \mathrm{~m} / \mathrm{s}$ 의 풍속이 감소한 것으로 예측되었다. 분석지점별로는 주간에는 $\mathrm{P} 1$ 과 $\mathrm{P} 8$ 이 $0.3 \mathrm{~m} / \mathrm{s}$ 로 가장 낮았고 $\mathrm{P} 3$ 과 $\mathrm{P} 4$ 가 각각 1.4 $\mathrm{m} / \mathrm{s}, 1.3 \mathrm{~m} / \mathrm{s}$ 로 다음으로 낮았으며, 북측에 위치한 $\mathrm{P} 10$ 이 $4.3 \mathrm{~m} / \mathrm{s}$ 로 가장 높은 값으로 해석되었다. 이는 P1과 P8은 단지 후류역에 위치하고 있어 건물에 의한
정체역이 발생되었기 때문에 낮은 값으로 나타난 것 으로 판단되었다. 야간의 평균풍속도 주간과 동일한 경향이었으며, P8이 $0.4 \mathrm{~m} / \mathrm{s}$ 로 가장 낮았고 P10이 3.2 $\mathrm{m} / \mathrm{s}$ 로 가장 높은 값으로 해석되었다.

\subsection{Case 4 : 건축물 신축이후(녹지율 $50 \%$ ) 여름철 온도,} 절대습도, 풍속 해석

단지내 녹지를 반영한 토지이용을 고려한 Case 4의 경우 주간 평균온도는 $25.7^{\circ} \mathrm{C}$ 이었고 야간 평균온도는 $22.8^{\circ} \mathrm{C}$ 이었다. 이는 Case 2 와 비교했을 때는 주간 0. $5^{\circ} \mathrm{C}$, 야간 $0.4^{\circ} \mathrm{C}$ 높은 값이며 Case 3 과 비교했을 때는 주간 $1.9^{\circ} \mathrm{C}$, 야간 $1.8^{\circ} \mathrm{C}$ 높게 나타났다. 즉 단지내 녹지

(a) Average of daytime

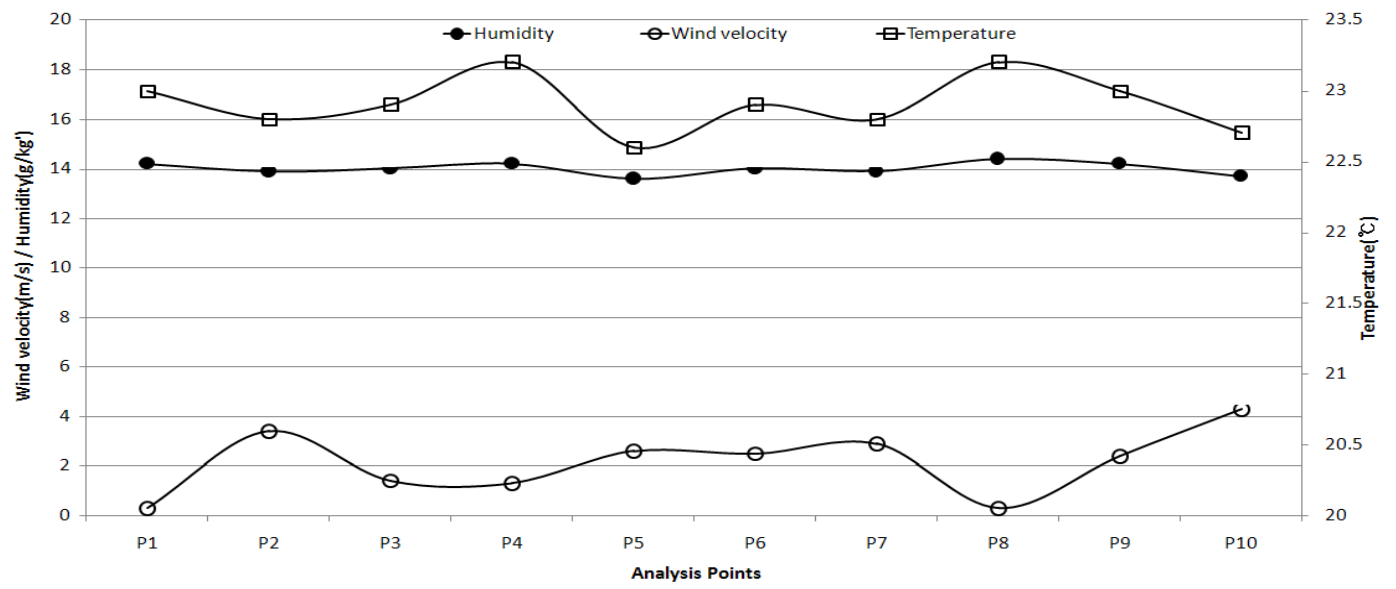

(b) Average of nighttime

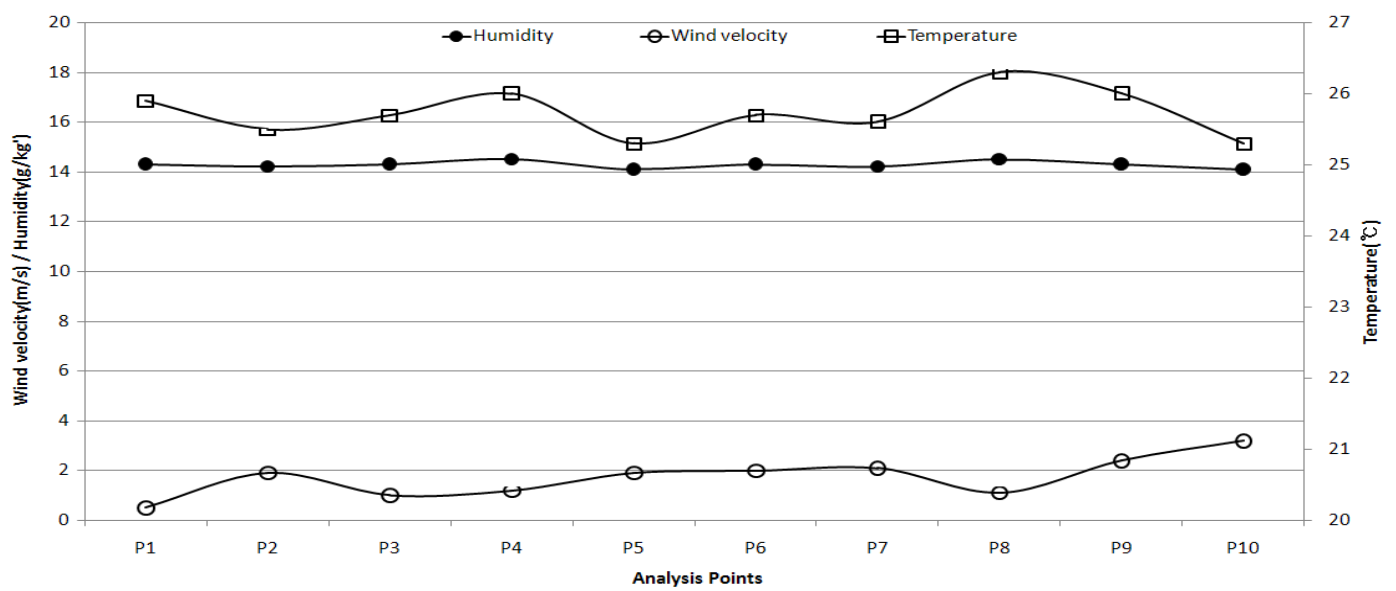

Fig. 8. Temperature, humidity and wind velocity of Case 4 at summer season. 
의 조성이 온도 저감효과에 큰 영향을 미치는 것으로 예측되었다(조와 안, 2006; 조 등, 2009). 이는 녹지의 조성에 따른 온도저감값을 연구한 山田(1992)이 제시 한 $0.11^{\circ} \mathrm{C}$ 과 유사하였다.

절대습도의 경우 주간 $14.0 \mathrm{~g} / \mathrm{kg}^{\prime}$, 야간 $14.3 \mathrm{~g} / \mathrm{kg}^{\prime}$, 일평균 $14.1 \mathrm{~g} / \mathrm{kg}^{\prime}$ 로, Case 3 대비 주간 $1.8 \mathrm{~g} / \mathrm{kg}^{\prime}$, 야간 $1.7 \mathrm{~g} / \mathrm{kg}$, 일간 $1.7 \mathrm{~g} / \mathrm{kg}$ '낮게 나타나, 녹지의 조성이 인체온열감의 불쾌적 요인에이 다소 개선된 것으로 판 단되었다. 풍속은 Case 3 과 동일하게 분석되었다.

\subsection{Case별 외부 열환경 변화 종합비교}

Fig. 9는 Case별 온도, 절대습도, 풍속의 평균값을 제시한 것이며 Fig. 10과 Fig. 11은 Case 2, 3, 4의 높 이별 온도와 풍속의 변화의 시뮬레이션 결과이다. 건 축물이 신축된 Case 3 의 경우 Case 2 와 비교했을 때 평균온도는 $2.8^{\circ} \mathrm{C}$ 증가하였고 최대 $3.1^{\circ} \mathrm{C}$, 최소 $2.1{ }^{\circ} \mathrm{C}$ 차이가 발생하였다. 녹지가 조성된 Case 4 의 경우 Case 3 대비 평균온도는 $1.9^{\circ} \mathrm{C}$ 낮아졌고 최대 $-1.7^{\circ} \mathrm{C}$, 최소 $-2.1^{\circ} \mathrm{C}$ 차이가 발생하여 녹지의 조성이 온도 저감 (a) Temperature
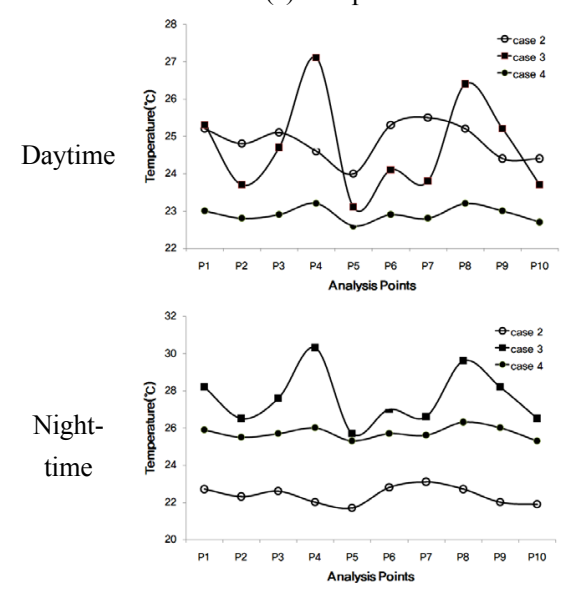

(b) Humidity
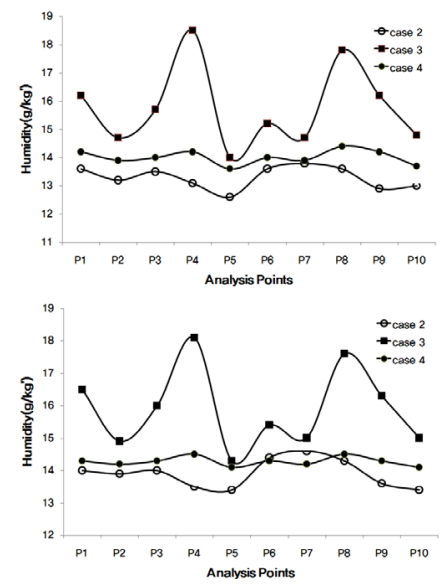

(c) Wind velocity

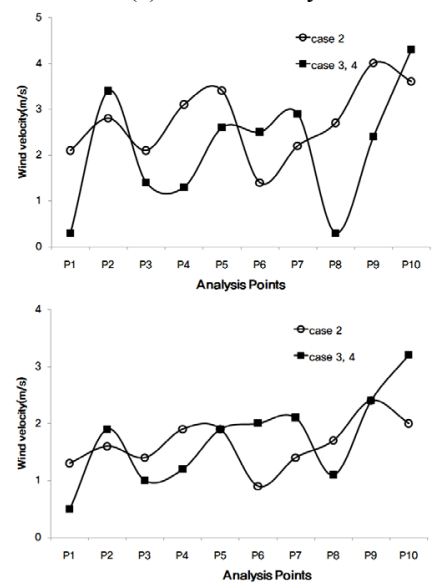

Fig. 9. Comparison of temperature, humidity and wind velocity at each cases.

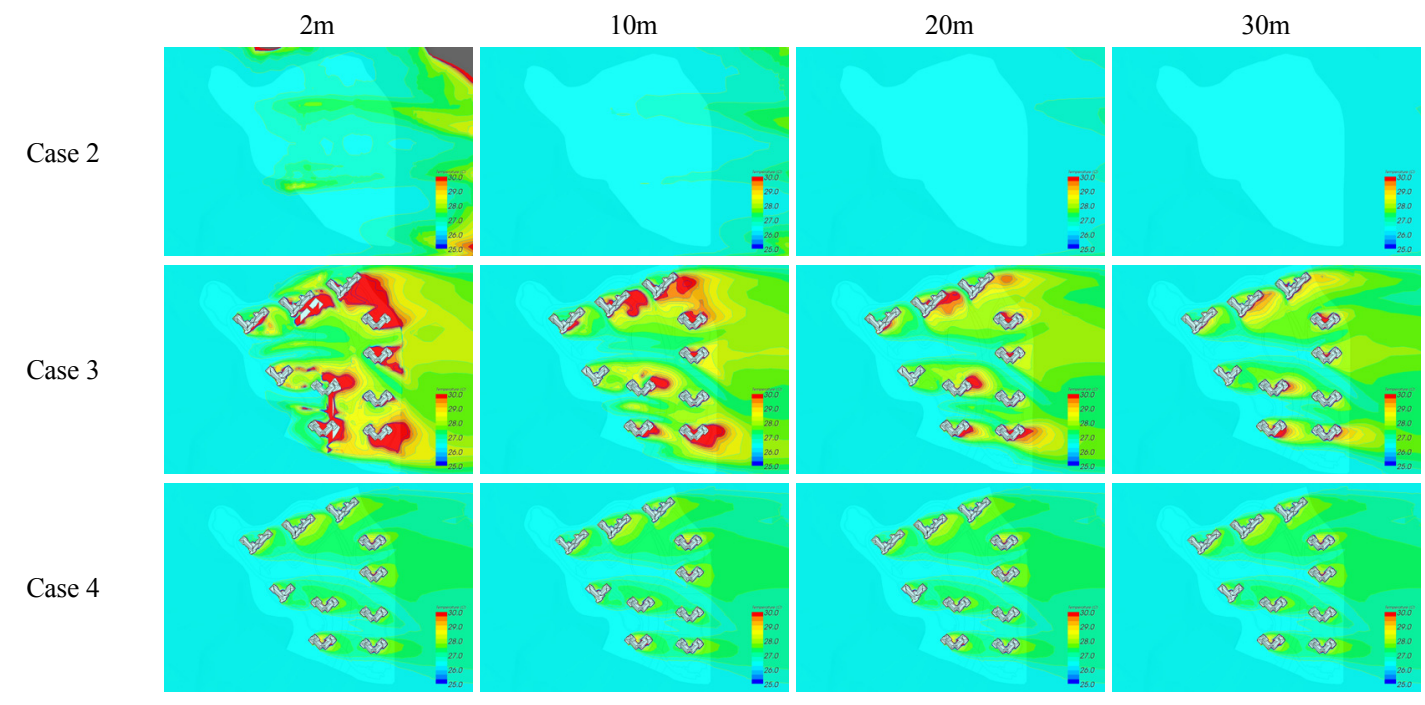

Fig. 10. Temperature prediction of case 2 , case 3 and case 4 at different height. 


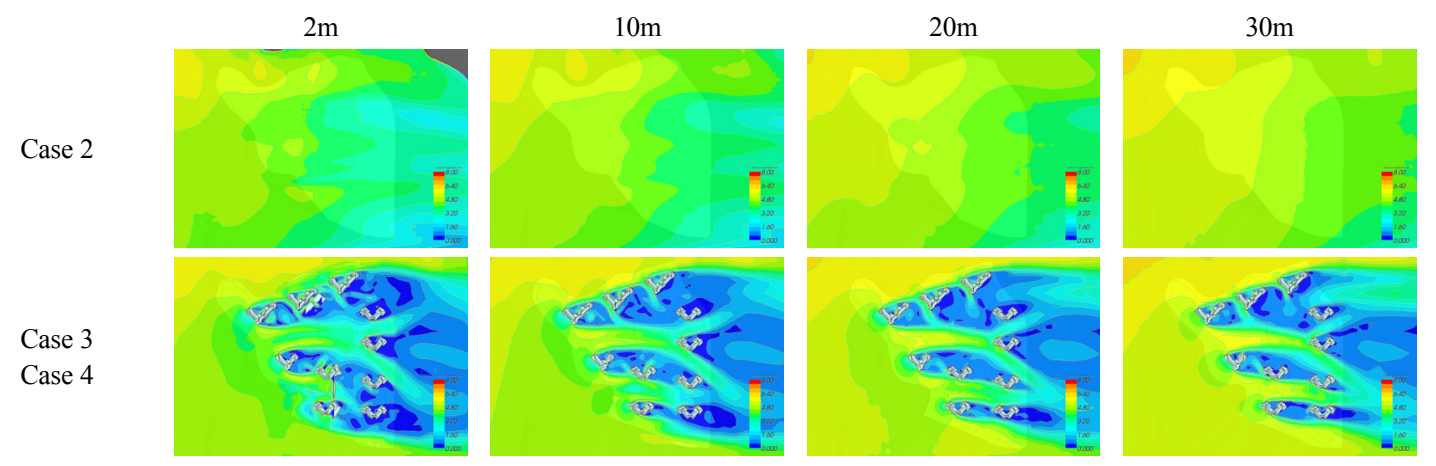

Fig. 11. Wind velocity prediction of case 2 , case 3 and case 4 at different height.

에 큰 영향임을 반영하고 있었다. Case 4 와 Case 2 를 주간온도를 비교한 결과 평균 $0.9^{\circ} \mathrm{C}$, 최대 $1.3^{\circ} \mathrm{C}$, 최소 $0.4^{\circ} \mathrm{C}$ 증가하는 것으로 예측되었으며 일간 전체를 대 상으로 살펴보면, Case 4 가 Case 3 보다는 $-2.1^{\circ} \mathrm{C}$ 차이 가 발생하였고 Case 2 와는 동일한 상태로 예측되었다.

절대습도의 경우 주간은 Case 4 가 Case 3 보다 평균 값 $-1.8 \mathrm{~g} / \mathrm{kg}^{\prime}$ (최대값 $-1.6 \mathrm{~g} / \mathrm{kg}^{\prime}$, 최소값 $-2.0 \mathrm{~g} / \mathrm{kg}^{\prime}$ ) 차 이가 이었으며 Case 2 대비는 평균 $0.7 \mathrm{~g} / \mathrm{kg}^{\prime}$ 증가하는 것으로 예측되었다. 일간 전체 평균 절대습도 변화는 Case 4 가 Case 3 대비 $-1.7 \mathrm{~g} / \mathrm{kg}^{\prime}$ 낮아졌고 Case 2 대비 $0.6 \mathrm{~g} / \mathrm{kg}^{\prime}$ 증가하는 것으로 분석되었다.

풍속은 Case 3 과 4 과 동일하게 분석되었으며 Case 2 보다는 주간평균 $0.6 \mathrm{~m} / \mathrm{s}$, 야간평균 $0.3 \mathrm{~m} / \mathrm{s}$, 일간평 균 $0.5 \mathrm{~m} / \mathrm{s}$ 풍속이 감소하는 것으로 예측되었다. 이는 건물 조성으로 인해 건물 후면의 정체역이 다수 발생 되었기 때문으로 판단되었다.

\section{5. 결 론}

본 연구는 도시지역의 건축물 신축 및 녹지배치에 따른 외부 열환경 변화 분석을 통해 도심내 열섬저감 에 대한 기초자료 확보를 목적으로 하였다. 연구대상 지인 경기도 일원의 공동주택을 사례로 4가지 Case의 해석조건을 설정하고 열환경에 관계되는 미기상 인자 를 예측하였다.

분석결과, 일간 평균 온도변화는 Case $3\left(26.5^{\circ} \mathrm{C}\right)>$ Case $4\left(24.6^{\circ} \mathrm{C}\right)>$ Case $2\left(23.9^{\circ} \mathrm{C}\right)$ 로 나타나 건축물의 신축이 신축전보다 약 평균 $2.5^{\circ} \mathrm{C}$ 증가하는 것으로 예 측되었고 녹지의 조성으로 약 $1.8^{\circ} \mathrm{C}$ 의 온도저감효과
가 있는 것으로 나타났다. 일간 평균 절대습도 변화는 Case 3(15.8 g/ $\left.\mathrm{kg}^{\prime}\right)>$ Case $4\left(14.1 \mathrm{~g} / \mathrm{kg}^{\prime}\right)>$ Case $2\left(13.5 \mathrm{~g} / \mathrm{kg}^{\prime}\right)$ 로 해석되어 녹지를 반영하지 않았을 경 우 $2.3 \mathrm{~g} / \mathrm{kg}^{\prime}$, 녹지를 반영했을 경우 $0.6 \mathrm{~g} / \mathrm{kg}^{\prime}$ 의 절대습 도 변화가 있었다. 일간 평균 풍속은 Case $2(2.3 \mathrm{~m} / \mathrm{s})$ $>$ Case 3 과 $4(1.8 \mathrm{~m} / \mathrm{s})$ 로서 건물의 신축이 단지내 일 간 평균 풍속을 약 $0.5 \mathrm{~m} / \mathrm{s}$ 감소시키는 것으로 예측되 었다.

본 연구는 단일 건축배치만을 대상으로 한 결과로 서 향후 건축물의 배치와 녹지의 배치를 다양한 조 건으로 설정하여 연구가 진행된다면, 건축물 및 도 시화 그리고 지역개발에 따른 외부 열환경을 최소화 가 가능할 것이다. 아울러 추후 연구로 녹지면적 뿐 만 아니라 녹지의 양적 인자도 함께 고려되어져야 할 것이다.

\section{참 고 문 헌}

기상청, 2010, 통계연보.

고은아, 2010, Envi-met에 의한 바람길 해석 및 건물배치 계획, 박사학위논문, 한밭대학교.

김상진, 서승직, 2002, Mellor-Yamada 모델을 이용한 도 시기후의 수치해석, 대한건축학회지, 18(10), 251-258.

김성실, 김영일, 2002 , 에너지 시뮬레이션을 위한 서울의 표준 외기 온도 및 습도 데이터, 대한설비공학회지, 11(1), 897-906.

김정호, 한봉호, 2006, 도시생태계 구조를 고려한 비오톱 유형 구분, 한국조경학회지, 34(2), 1-17.

김정호, 윤용한, 2011, 옥상녹화 및 토양피복변화가 단독 주택지 외부 열환경에 미치는 영향 분석, 환경정책 
연구, 10(1), 27-47.

김주수, 박화란, 박병용, 김태연, 이승복, 2010, 하절기 아 파트단지의 열환경 실측과 $\mathrm{CFD}$ 를 이용한 해석방법 검증에 관한 연구, 대한건축학회지, 26(5), 335-342.

김태연, 김정태, 노지웅, 2000 , 간이 대류 - 복사 - 열관류 연성 시뮬레이션에 의한 대류열전달량 해석, 대한건 축학회지, 18(1), 469-474.

김찬중, 1998 , 전산유체역학, 1 판, 문운당.

남중우, 2008, 친환경 단지 실측 및 CFD시뮬레이션 검증 을 통한 아파트 단지내 열환경 개선방안, 석사학위 논문, 연세대학교.

류남형, 유병림, 2006, 투 - 보수성 시셈트 콘크리트 포장 의 열물성 및 수분보유 특성이 표면온도에 미치는 영향, 한국조경학회지, 31(4), 21-36.

박필원, 2009, 공동주택 외부공간의 지표면 특성이 단지내 열환경에 미치는 영향, 석사학위논문, 성균관대학교.

서안선, 2009, 바람길을 고려한 아파트 단지계획, 석사학 위논문, 한양대학교.

서응철, 2007 , 도시열섬 완화를 위한 제도 개선, 한국생 태환경건축학회지, 7(2), 17-23.

석호태, 김호진, 최동호, 2009 , 돔경기장의 현장실측과 $\mathrm{CFD}$ 해석의 비교 - 분석에 관한 연구, 대한건축학회 지, 25(8), 357-364.

손원득, 박정한, 박경순, 2009 , 신재생에너지 적용이 도 시열섬방지에 미치는 기여도 분석, 정기학술발표회 논문집, 대한설비공학회, 508-513.

손원득, 이성, 2004, 도심지의 온열성상에 관한 연구 -도 심지 온열환경 예측모델을 위한 실측조사-, 대한설 비공학회지, 16(10), 984-989.

윤성환, 김성하, 2008 , 부산시 해운대구의 하기 도시 고 온화 현상과 토지피복 구성과의 상관관계, 한국태양 에너지학회 28(2), 19-27.

윤소원, 이동근, 김창석, 정회성, 조적호 1999 , 지속가능 한 도시의 평가규모 개발에 관한 이론적 연구, 대한 국토도시계획학회지, 34(6), 145-159.

윤재옥, 주재성, 2011, CFD 시뮬레이션을 이용한 계절의 주풍향, 부풍향별 도시 기류환경 예측 연구, 대한건 축학회지, 27(1), 213-220.

이경회, 1987 , 건축환경계획, 문운당, 262.

이동근, 전성우, 1997 , 도시지속성지표 구축을 위한 개념 적 연구-환경적 지속성 지표를 중심으로-, 한국환경 영향평가학회지, 6(1), 33-45.

이상우, 1997, 건축환경계획론, 태림문화사, 28.

이수동, 2007 , 택지개발지구에서의 비오톱 평가에 기초 한 환경생태계획 기법 연구, 한국조경학회지, 34(6),
22-38.

이용준, 김정호, 오은주, 조진영, 김진호, 2010, 공동주택 단지내 외부환경이 도시열섬에 미치는 영향 요인 분 석, 정기학술발표회논문집, 한국환경생태학회, 20(2), 201-203.

이재준, 이상문, 2001, 환경친화적 도시계획 수립을 위한 환경성 평가 및 평가지표 적합성 판단 연구, 대한국 토도시계획학회지, 36(2), 7-17.

정응호, 류지원, 김대욱, 차재규, 2007 , 도시 열섬현상 완 화를 위한 녹지네트워크 및 바람길 구축, 한국지리 정보학회지 10(1): 00-00.

조성모, 윤용한, 류을렬, 박봉주, 김원태, 2009 , 도시내 용 도지역의 토지피복형태가 열섬현상에 미치는 영향, 한국환경과학회지, 18(2), 169-176.

조현길, 안원태, 2006, 도시수목식재와 미기후 개선의 상 관성 규명, 한국조경학회지, 34(5), 70-75.

한국환경과학회, 2009 , 그린조경학, 1 판, 문운당, 212252.

吉田伸治, 大岡龍三, 持田燈, 富永偵秀, 村上周二, 2000, 樹木モデルを組み込んだ對流・放射・濕氣 輸連成 解析にとる樹木の屋外熱環境緩和效果の檢討, 日本 建築學會計劃系, 536, 87-94.

村上周上，1997, 關東地方における土地利用狀況の変化 と流れ場・溫度場の關系Mellor- Yamada型の都市 氣候モデルによる局地氣象解析, 日本建築學會計劃 系, 491, 31-39.

Ashrae, 2009, Handbook of Fundamentals.

Akbari, h., Davis, S., Huang, J., Liu, P., Taha, H., 1992, The urban heat island causes and impacts In $\mathrm{H}$ Akbari, S Davis, S. Dorsano. J. Huang, and S. Winnett, eds, Cooling Our Communities Washington, DC. US. Government Printing Office, 5-26pp.

Givoni, B., 1998, Glimate Considerations in Building and Urban Design New York, Van Nostrand Remhold.

Huang, J., Akbri, H., Taha, H., Rosenfeld, A., 1987, The potential of vegeation in reducing summer cooling loads in residential buildings. Journal of Climate and Applied Meteorology 26, 1103-1116.

Profous, G. V., 1992, Trees and urban forestry in Beijing, China. Journal of Arboriculture, 18, 145-153.

Olgyay, V., 1963, Design with Climate, Princeton University Press. 